\title{
Vegetation Expansion on the Tibetan Plateau and Its Relationship with Climate Change
}

\author{
Zhipeng Wang ${ }^{1,2}\left(\mathbb{D}\right.$, Jianshuang $\mathrm{Wu}^{3}\left(\mathbb{1}\right.$, Ben $\mathrm{Niu}^{2}$, Yongtao $\mathrm{He}^{1,2}$, Jiaxing $\mathrm{Zu}^{4}$, Meng $\mathrm{Li}^{5}$ \\ and Xianzhou Zhang ${ }^{1,2}$,* \\ 1 Lhasa Plateau Ecosystem Research Station, Key Laboratory of Ecosystem Network \\ Observation and Modeling, Institute of Geographic Sciences and Natural Resources Research, \\ Chinese Academy of Sciences, Beijing 100101, China; wangzp.18b@igsnrr.ac.cn (Z.W.); \\ heyt@igsnrr.ac.cn (Y.H.) \\ 2 College of Resources and Environment, University of Chinese Academy of Sciences, Beijing 100190, China; \\ niub@igsnrr.ac.cn \\ 3 Institute of Environment and Sustainable Development in Agriculture, Chinese Academy of \\ Agricultural Sciences, Beijing 100081, China; wujianshuang@caas.cn \\ 4 Key Laboratory of Beibu Gulf Environment Change and Resources Utilization of Ministry of Education, \\ Nanning Normal University, Nanning 530001, China; zujx.15b@igsnrr.ac.cn \\ 5 School of Geographic Sciences, Nantong University, Nantong 226007, China; limeng@ntu.edu.cn \\ * Correspondence: zhangxz@igsnrr.ac.cn; Tel.: +86-10-6488-9690
}

Received: 1 December 2020; Accepted: 16 December 2020; Published: 18 December 2020

\begin{abstract}
The natural shift in land cover from non-vegetated to vegetated land is termed as vegetation expansion, which has substantial impacts on regional climate conditions and land surface energy balance. Barrens dominate the northwestern Tibetan Plateau, where vegetation is predicted to expand northwestward with the ongoing climate warming. However, rare studies have confirmed such a forecast with large-scale vegetation monitoring. In this study, we used a landcover dataset, classified according to the International Geosphere-Biosphere Program criteria, to examine previous model-based predictions and the role of climate on the expansion rate across the plateau. Our results showed that shrublands, open forests, grasslands, and water bodies expanded while evergreen and deciduous broadleaf forests, croplands and barrens shrank during the period 2001-2018. Vegetation expanded by $33,566 \mathrm{~km}^{2}$ accounting for about $1.3 \%$ of the total area of this plateau and the land cover shifting from barrens to grasslands was the primary way of vegetation expansion. Spatially, the vegetation expanded northwestward to lands with colder, drier, and more radiation in the climate. Increasing precipitation positively correlated with the vegetation expansion rate for the arid and semi-arid northwest Tibetan Plateau and warming contributed to the vegetation expanding in the semi-humid southeast Tibetan Plateau. Our results verified the predictions of models and highlighted the "greening" on barrens in recent years.
\end{abstract}

Keywords: land cover change; MCD12Q1; vegetation expansion; Tibetan Plateau; climate change

\section{Introduction}

The warming rate at high latitudes and elevations is higher than the averages of the northern hemisphere and those of the world in recent decades [1,2], and the amplification is mainly attributed to the cryospheric snow-ice feedback [1,3,4]. Greening has been observed at high latitudes via satellite records, which is interpreted as warming induced shrub expansion, tree line advance and tundra growth, which has contributed to global warming [5]. As reported, shrub cover has increased, and the tree line has rose upward and expanded northward in Alaska [6-9]. The transition is thought to be one 
of the important large-scale ecological responses to global climate change and could alter the global carbon cycle and land surface energy budget [8-11].

Warming increases the net primary productivity as well as carbon uptake of tundra and alpine vegetation and elevates respiration, which may result in a significant change to the terrestrial carbon cycle and soil carbon storage [12-14]. For instance, Natali et al. [12] and Sistla et al. [13] conducted warming experiments in the Arctic tundra and found that warming increases plant biomass and woody dominance. The vegetation growth and dominant species transition-induced "greening" also has positive feedback for warming by reducing the land surface albedo and increasing the radiation absorption $[10,11]$. In Siberia, Blok et al. [10] observed in four study sites that the "greenness" (represented by the normalized difference vegetation index, NDVI) is negatively related to albedo. Furthermore, the land-atmosphere interactions, like the hydrological processes, will be modified by altered land surface properties-induced changes in the surface heating [2,15]. For example, land cover changing from the bare ground to vegetated land can enhance evapotranspiration, accelerate vapor's vertical ascending and then result in more rainfalls [15]. Therefore, it is crucial to monitor the land cover change and explore its responses to climate change, particularly in the high latitudes and elevations, where the land is undergoing a higher warming rate and the vegetation might play a role of forerunner and feedbacks $[5,16]$.

Located in central Asia and southwest China, the Tibetan Plateau (TP) is a part of the global cryosphere and known as the "Third Pole" on the earth [17], which covers a total area of more than 2.5 million $\mathrm{km}^{2}$ with an average elevation over $4000 \mathrm{~m}$. Due to the high elevation, its climate is characterized by low air temperature, intense solar radiation, and distinct wet and dry seasons [18]. Under such harsh and varying environments, diverse land cover types, including forests, shrublands, meadows, steppes, and deserts, as well as water bodies and glaciers, are widely "nurtured" and distributed on this plateau. Meanwhile, the TP is the headwater area of major rivers in Asia, such as the Yangtze, Yellow, Brahmaputra, Mekong, and Indus rivers [19], and the provision of fresh water is tightly related with climate change and affects both natural and societal sustenance within the TP, as well as of the counties downstream in South Asia.

The TP plays a profound role in the regional climate (e.g., summer monsoon in Asia) due to its elevated topography and thermal forcing [18,20-24]. For example, anomalies in cyclones (anticyclones) over the western TP are associated with the enhanced (weakened) westerly flow along its southern boundary, cutting (providing) the moisture supply from the Indian Ocean to the Indian Subcontinent [23]. The landcover transitions, including snow melting, glacier shrinking, and vegetation greening (browning) and expansion, are primary drivers affecting land-atmosphere interactions [15,25-27]. It is reported that the glaciers are rapidly retreating and both warming and precipitation changes accompanying atmospheric circulation patterns should be responsible $[27,28]$. In a study conducted in the Qinghai-Tibetan Plateau, Shen et al. [25] found that the greening TP is likely to attenuate land surface warming, which is contrary to the lessons in high latitudes [10]. Based on an atmospheric general circulation model (GCM), Li and Xue [15] found that the landcover shift from vegetation to barrens decreases the land surface radiation absorption and weakens the surface heating effects. Moreover, the land cover change-induced air temperature dropping and cyclone weakening may reduce precipitation.

In recent decades, the TP experienced remarkable climate change [18]. Specifically, the air temperature on the whole TP has risen by $0.2^{\circ} \mathrm{C} / 10 \mathrm{a}$ for the period $1960-2010$, and even exceeded $0.8^{\circ} \mathrm{C} / 10 \mathrm{a}$ in the arid northern area [29]. Seasonally, the warming rate in the winter and autumn is significantly higher than that of other seasons or annual warming rate [29-31]. Meanwhile, the increased rate of the minimum temperature of the plateau is higher than the maximum temperature and the mean temperature [30-32]. This decreased the difference in diurnal temperature range (DTR) and it is mainly induced by the increase in cloud amount at night, which enhanced the atmospheric counter radiation [33]. Precipitation over the whole plateau increased slightly and was accompanied by a sizeable interannual variability and spatial heterogeneity $[18,29,30]$. Seasonally, winter and spring 
precipitation increased significantly more than in the past thirty years [31,34]. Spatially, the northwest TP experienced a significant increase in the past four decades [35].

It is widely reported and discussed on the structure and function of alpine vegetation on the TP responding to climate change [36-40]. Based on in situ observations and experiments, Liu et al. [40] found that warming increases grass abundance and lower sedge abundance, meanwhile the plant communities tend to shift more net primary productivity (NPP) to belowground (deeper root system) in order to acquire more water in response to drought. With satellite large-scale monitoring, the vegetation index (e.g., NDVI) was extensively used to detect the vegetation phenology and simulate NPP $[36,38,41,42]$. As reported, the green-up dates derived from NDVI changed in response to the spring and winter warming [36]. Over one third of the total grassland significantly increased in NDIV-based NPP during the period 1982-2009 [42]. So far, the short time scale of experimental observations and satellite records is one of the limitations in understanding vegetation responding to long-term climate change.

Despite the uncertainty in the rate and patterns of future climate change [43], evaluations on the long-term responses of vegetation are still issues of our concern. Based on climate scenarios and ecosystem models, some studies predicted the vegetation change on the TP in the future [44-46]. Specifically, based on the modified equilibrium terrestrial biosphere model (BIOME), Ni [44] and Zhao et al. [45] predicted the shrinking of sparse vegetation and desert, meanwhile the northwestward expanding of vegetation and increase in water bodies. Gao et al. [46] modified the Lund-Potsdam-Jena Dynamic Global Vegetation Model (LPJ) model and predicted that alpine steppes would expand northwestward and dominated the western and northern plateau under Representative Concentration Pathway 4.5 (RCP4.5) and RCP8.5 climate scenarios. However, rare studies have examined the results with field evidence and large scale vegetation monitoring, especially in the northwestern plateau, where barrens are widely distributed and the vegetating may regulate the regional climate in significant ways.

Satellite-based remote sensing is one of the practical methods for vegetation monitoring at large scales. For example, Anderson et al. [47] recently thresholded NDVI at 0.1 to indicate the presence/absence of vegetation on the subnival Hindu Kush Himalaya and found that the vegetation was expanding to become higher in elevation. However, there is currently no consensus on how to determine the threshold value of the vegetation index (e.g., NDVI) to indicate the presence and absence of vegetation at a large spatial scale. With the development and optimization of methods in land cover classification, it is feasible to monitor land cover change with remote sensing [36,48].

Thus, can we use the current satellite records to verify the model-based predictions on vegetation expansion on the TP? What is the role of climate change in the rate of vegetation expansion? To fill the gaps above, in this study, we hired a remote sensing-based land cover classification with annual intervals to monitor changes in land cover, especially the "movement" of vegetation, and its response to climate on the high-elevated TP. Specifically, we concretely aim to (1) analyze the variations of different vegetation types on the TP during the period 2001-2018; (2) detect the trends of vegetation expansion in climate and geography; and (3) examine the relationship between vegetation expansion rate and climate change.

\section{Materials and Methods}

\subsection{Study Area}

The Tibetan Plateau (TP) is located at southwest China and considered an ecological security barrier for East Asia [49]. Mean annual air temperature is below $0{ }^{\circ} \mathrm{C}$ in most places on the TP, and generally decreases from the East to West [50]. Annual precipitation decreases from the southeast (over $1000 \mathrm{~mm}$ ) to the northwest (less than $50 \mathrm{~mm}$ ) [19,51]. Mean yearly solar radiation over the entire $\mathrm{TP}$ is about $210 \mathrm{~W} / \mathrm{m}^{2}$ [52], and increases from the southeast to northwest and also with increasing elevation. There are arid, semi-arid semi-humid and humid zones across the TP (Figure 1). According to the China Ecological Geographical Division of China, which is a map based on temperature, wet and 
dry conditions, the TP can be divided into the arid, semi-arid, semi-humid and humid zones (Figure 1). Under the International Geosphere-Biosphere Program (IGBP) classification scheme in 2018 (Figure 1), the forests, including needleleaf forest, broadleaf forest, and mixed forest, accounted for about $5 \%$ of the entire TP and were mainly distributed in southern Tibet. The open forests accounted for about $3.2 \%$ of the TP area and spread in southeast TP. Open and closed shrublands summed together to $0.35 \%$ of the land surface and scattered in the central and western Tibet. Grasslands dominated the TP and covered $51.8 \%$ of the whole plateau. Land cover types including urban-built, croplands and wetlands shared relatively small proportions, merely $0.04,0.28$ and $0.05 \%$, respectively. As the second-largest land cover type, barren lands were mainly distributed in northern TP, accounting for $36.8 \%$ of the total area of this plateau. The area percentage summed up to $1.3 \%$ for both permanent snow and ice and water bodies.

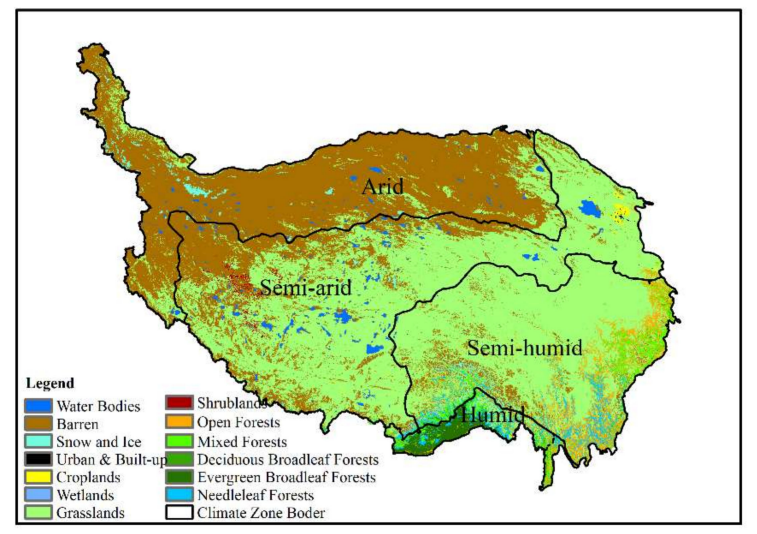

Figure 1. Land cover types on the Tibetan Plateau classed in 2018 under the International GeosphereBiosphere Program (IGBP) classification scheme and the division of climate zones.

\subsection{Land Cover Dataset}

The Moderate Resolution Imaging Spectroradiometer (MODIS) Land Cover Type Version 6 data product (MCD12Q1C6) supplies the global land cover types at $500 \mathrm{~m}$ spatial resolution and yearly intervals (from 2001 to present). The dataset contains six classification schemes and is derived using MODIS Terra and Aqua reflectance data [53,54]. A hierarchical classification model was used to produce the land cover data, where the classes included in each level of the hierarchy reflected structured distinctions between land cover properties. The four major processing steps involved: (1) pre-processing the input nadir BRDF (Bidirectional Reflectance Distribution Function)-adjusted surface reflectance (NBAR) data with penalized smoothing splines; (2) classification using random forests with annual features; (3) modifications with ancillary information; and (4) stabilization of the classification with the hidden Markov model (HMM) [55]. More details and improvements about the data can be found elsewhere [53-56]. In this study, we collected the data (MCD12Q1C6) with $500 \mathrm{~m}$ spatial resolution from the National Aeronautics and Space Administration (NASA), and the classifications under the IGBP classification scheme were selected from 2001 to 2018.

Before the analysis, we merged several vegetation classes. The evergreen and deciduous needleleaf forests were integrated as needleleaf forests. The close and open shrublands were merged to shrublands, and the woody savannas and savannas were combined into savannas. Savannas, however, are tropical grassland with a varying degree of tree coverage, and it is unlikely to exist on the TP. Therefore, in order to avoid the misleading, here we referred to the Food and Agricultural Organization (FAO) land cover classification system and classified savannas as open forests [53].

\subsection{Gridded Climate and Elevation Datasets}

We downloaded the daily precipitation and temperature data recorded by meteorological stations within the TP from the China Meteorological Data Service Center (CMDC/CMA, http://data.cma.cn/). 
Monthly precipitation (Pre) and mean air temperature (Tem) station-level records during 2001-2018 were calculated based on daily records. Then, we interpolated the meteorological data into grids with ANUSPLIN4.3 software [57], which is widely used to produce gridded climate variables over the TP $[39,58,59]$. In this step, we used the thin spline smoothing method while inputting the elevation data as the third independent variable to consider the orographic effect on climate, which was recommended and would make a big improvement to the accuracy, especially for precipitation [57,60]. Monthly surface downward shortwave radiation with $0.1^{\circ}$ spatial resolution was obtained from the Institute of Tibetan Plateau Research, Chinese Academy of Sciences [61,62]. Based on the monthly gridded climate data, we calculated the annual precipitation (Pre), mean annual air temperature (Tem), mean annual radiation (Rad), growing season (May-October) precipitation (GSP), mean growing season air temperature (GST) and mean growing season radiation (GSR). The elevation data in $250 \mathrm{~m}$ spatial resolution were obtained from the Shuttle Radar Topography Mission (SRTM) (http://srtm.csi.cgiar.org). The data were derived from the USGS/NASA SRTM data and processed to provide seamless continuous topography surfaces, and areas with regions of no data in the original SRTM data were filled using interpolation methods [63]. Finally, we resampled all the gridded climate dataset to match the land cover data at $500 \mathrm{~m}$ spatial resolution with bilinear method [64-67].

\subsection{Definition of Vegetation Expansion}

In this study, the vegetation expansion was defined as the land cover transition from non-vegetated to vegetated lands, meanwhile, the conversion remains steady. In order to filter the noise caused by the data quality in labeling the land cover type [53], we recognize the year of vegetation expansion based on detecting whether the land is non-vegetated before but vegetated in all the following years. For example, pixels detected to be the vegetation expansion in 2010 are those pixels that were previously labeled non-vegetated but all the years later were identified to be vegetated. Otherwise, the temporary shifts between land cover types will be attributed to noises. The definition of vegetated and non-vegetated land cover and a brief description on the IGBP criteria were merged in Table 1. The vegetation expansion rate is defined as the number of pixels detected to be the vegetation expansion each year in this study. A brief flow chart on the steps of this study is in Figure A1.

Table 1. Definition of vegetated and non-vegetated lands and a brief description on the criteria of the IGBP classification.

\begin{tabular}{|c|c|c|}
\hline Name & Vegetated/Non-Vegetated & Description \\
\hline Evergreen broadleaf forests & Vegetated & $\begin{array}{l}\text { Evergreen broadleaf tree dominated. } \\
\text { Canopy }>2 \mathrm{~m} \text {. Tree cover }>60 \% \text {. }\end{array}$ \\
\hline Deciduous broadleaf forests & Vegetated & $\begin{array}{l}\text { Deciduous broadleaf tree dominated. } \\
\text { Canopy }>2 \mathrm{~m} \text {. Tree cover }>60 \% \text {. }\end{array}$ \\
\hline Needleleaf forests & Vegetated & $\begin{array}{l}\text { Needleleaf trees dominated. } \\
\text { Canopy }>2 \mathrm{~m} \text {. Tree cover }>60 \% \text {. }\end{array}$ \\
\hline Mix forests & Vegetated & $\begin{array}{c}\text { Neither deciduous nor evergreen tree } \\
\text { dominated. Canopy }>2 \mathrm{~m} \text {. Tree cover }>60 \% \text {. }\end{array}$ \\
\hline Shrublands & Vegetated & $\begin{array}{l}\text { Woody perennials dominated. } 1-2 \mathrm{~m} \text { height. } \\
\text { Cover }>10 \% \text {. }\end{array}$ \\
\hline Open forests (Savannas) & Vegetated & Canopy $>2$ m. $10 \%<$ Tree cover $<60 \%$. \\
\hline Wetlands & Vegetated & $30 \%<$ Water cover $<60 \%$. Vegetation $>10 \%$. \\
\hline Grasslands & Vegetated & $\begin{array}{c}\text { Herbaceous annuals dominated. } \\
\text { Canopy }<2 \mathrm{~m} \text {. }\end{array}$ \\
\hline Croplands & Vegetated & Cultivated cropland $>60 \%$. \\
\hline Urban and Built-up Lands & Non-vegetated & Building cover $>30 \%$ \\
\hline Snow and ice & Non-vegetated & $\begin{array}{l}\text { Snow and ice cover }>60 \% \text {. } \\
\text { Time }>10 \text { months. }\end{array}$ \\
\hline Barren & Non-vegetated & $\begin{array}{c}\text { Sand, rock, soil cover }>60 \% . \\
\text { Vegetation }<10 \% .\end{array}$ \\
\hline Water bodies & Non-vegetated & Permanent water bodies cover $>60 \%$. \\
\hline
\end{tabular}




\subsection{Statistical Analysis}

We adopted linear models to obtain the trend lines of vegetation expansion along climatic and geographic gradients and the Pearson correlation coefficients $(R)$ with the $t$-test at the 0.1 and 0.05 levels was calculated to indicate the direction and strength of the statistic relationship, respectively. The responses of the vegetation expansion rate (number of pixels detected to be vegetation expansion each year) to climate variables (GST, GSP and GSR) were examined with linear and non-linear (quadratic, natural log, and exponential) models.

\section{Results}

\subsection{Land Cover Change on the TP}

We examined changes in the number of the pixels for each land cover type for the period 2001-2018 (Figures 2 and 3) and found that the noticeable change was in the expansion of vegetated lands and the shrinkage of barren lands (Figure 2). Compared with the classification in 2001, the vegetated coverage classified in 2018, including forests, shrublands, open forests, grasslands and croplands, increased by 134,264 pixels, which is approximately equal to $33,566 \mathrm{~km}^{2}$ and $1.3 \%$ of the total area of the TP.

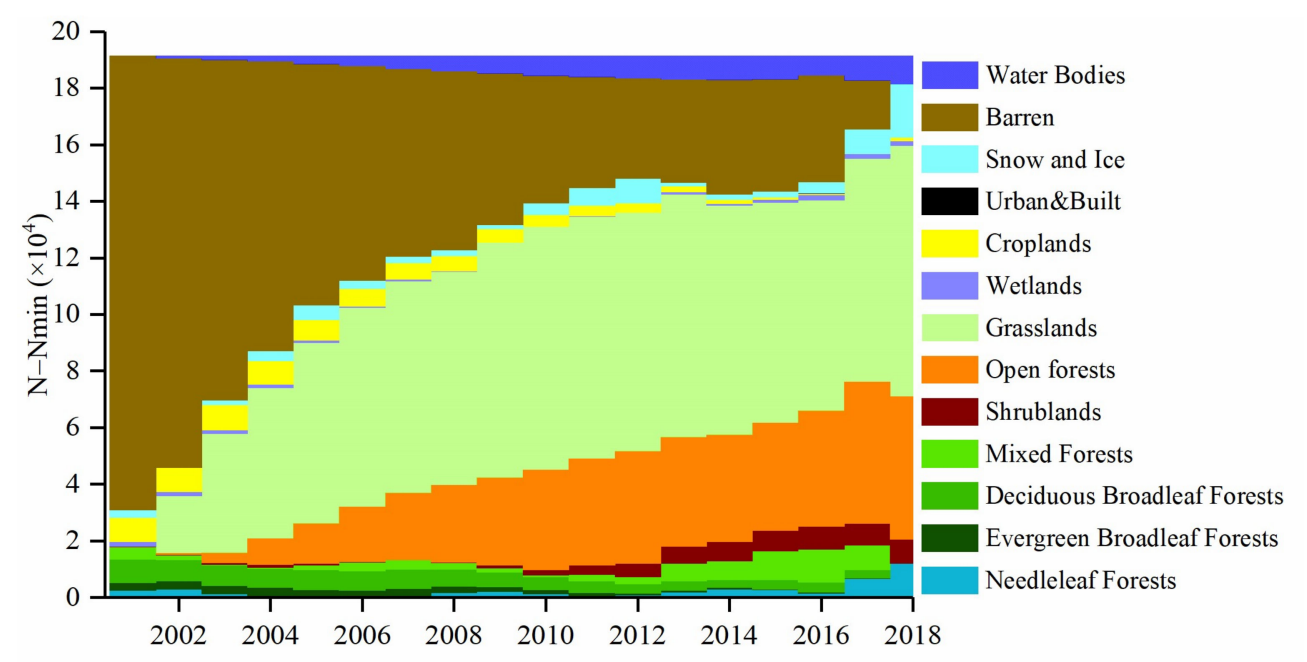

Figure 2. Interannual variations of the difference between $\mathrm{N}$ (number of pixels) and Nmin (minimum $\mathrm{N})$ during the period 2001-2018 for each land cover type. The N-Nmin indicates the relative portion of different land cover types for pixels that have changed during the period.

Specifically, the coverage (represented by the number of pixels, N) change differs among land cover types during the period 2001-2018 (Figure 3). The area of evergreen and deciduous broadleaf forests and croplands continuously declined (Figure $3 b, c, i)$, while the size of open forests and water bodies increased (Figure 3f,l) during the period 2001-2018. The area of grasslands became stable after a significant increase (Figure 3g). The wetlands coverage first decreased and then recovered with the turning point around 2010 (Figure 3h). Needleleaf forests showed a relatively flat line from 2001 to 2015 , and then it significantly increased (Figure 31). The coverage of mixed forests slightly increased for the period 2010-2016 and then decreased (Figure 3d). The shrublands significantly increased after 2007 (Figure 3e) and urban and built-up lands exponentially increased during the study period (Figure 3j). 

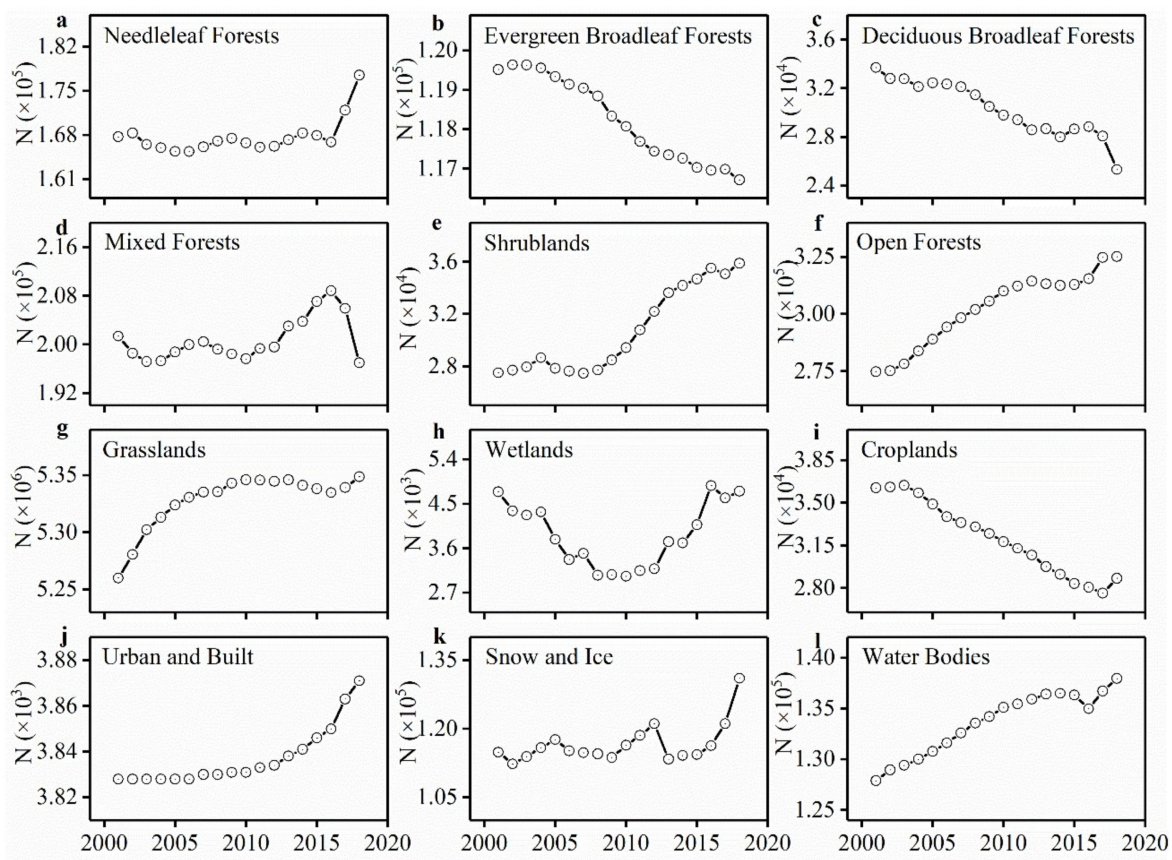

Figure 3. Interannual variations of the coverage of different land cover types during the period 2001-2018. The $\mathrm{Y}$ axis scaling of $(\mathbf{a}, \mathbf{b}, \mathbf{d}, \mathbf{f}, \mathbf{k}, \mathbf{l})$ is $\mathrm{N} \times 10^{5}$; and the $\mathrm{Y}$ axis scaling of $(\mathbf{c}, \mathbf{e}, \mathbf{i})$ is $\mathrm{N} \times 10^{4}$, while it is $\mathrm{N} \times 10^{6}$ for $(\mathbf{g})$, but $\mathrm{N} \times 10^{3}$ for $(\mathbf{h}, \mathbf{j})$.

\subsection{Vegetation Expansion on the TP}

We summarized the vegetation expansion from non-vegetated lands to different vegetated types over all the TP during four subperiods from 2001 to 2018 (Table 2). We found that the transition from non-vegetated lands to grasslands dominated the vegetation expansion on the TP during the whole study period (Table 2).

Table 2. Statistics on the number of pixels (N) for each type of vegetation expansion from non-vegetated lands (NV) to different vegetation types at subperiods between 2001 and 2018.

\begin{tabular}{ccccc}
\hline \multirow{2}{*}{ Transition Type } & $\mathbf{2 0 0 1 - 2 0 0 5}$ & $\mathbf{2 0 0 5 - 2 0 0 9}$ & $\mathbf{2 0 0 9 - 2 0 1 3}$ & $\mathbf{2 0 1 3 - 2 0 1 8}$ \\
\cline { 2 - 5 } & $\mathbf{N}$ & $\mathbf{N}$ & $\mathbf{N}$ & $\mathbf{N}$ \\
\hline NV-Grasslands & 69,292 & 46,699 & 40,223 & 71,738 \\
NV-Open Forests & 18 & 26 & 23 & 8 \\
NV-Shrublands & 750 & 674 & 665 & 2579 \\
NV-Forests & 5 & 2 & 6 & 0 \\
NV-Wetlands & 185 & 201 & 281 & 363 \\
\hline
\end{tabular}

In different climate zones, we analyzed the spatial patterns (Figure 4) and the frequency distribution of vegetation expansion along environmental gradients (Figure 5). The expansion of vegetation in the arid and semi-arid TP expanded near the boundaries and mainly took place during the subperiod 2013-2018 (Figure 4; Figure 5). For the arid zone, the vegetation expanded in lands where the multi-year Tem was in the range from -4.0 to $2.2{ }^{\circ} \mathrm{C}$ (quartile to third quartile of all the records), Pre was in the range of $112-211 \mathrm{~mm}$, Rad was in the range of $245-256 \mathrm{~W} / \mathrm{m}^{2}$ and elevation was in the range of $3387-4498 \mathrm{~m}$. For the semi-arid zone, vegetation expanded in the lands with Tem ranging from -5.0 to $0.1^{\circ} \mathrm{C}$, Pre ranging from 214 to $357 \mathrm{~mm}$, Rad ranging from 253 to $276 \mathrm{~W} / \mathrm{m}^{2}$ and elevation ranging from 4650 to $5227 \mathrm{~m}$. While in the semi-humid TP, vegetation mainly expanded in the western part and primarily took place for during the subperiod 2001-2005 (Figures 4 and 5). There, the vegetation expansion mainly took place in the lands with Tem ranging from -1.6 to $0.98{ }^{\circ} \mathrm{C}$, Pre ranging from 
605 to $685 \mathrm{~mm}$, Rad ranging from 202 to $236 \mathrm{~W} / \mathrm{m}^{2}$ and elevation ranging from 4642 to $5117 \mathrm{~m}$. Vegetation expansion can hardly be observed in the humid zone (Figure 4).

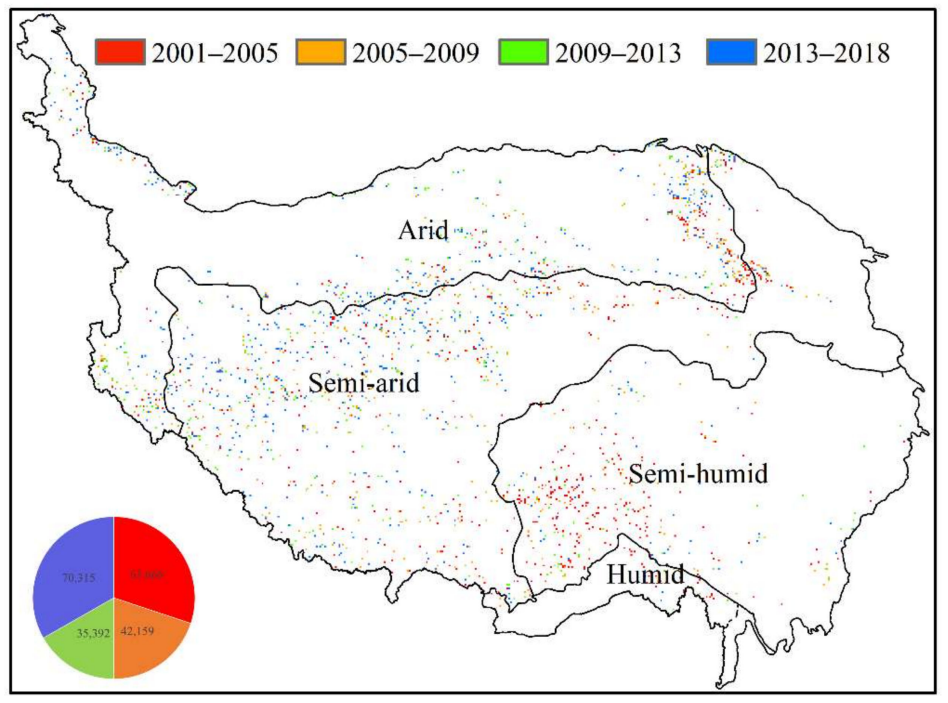

Figure 4. Vegetation expansion in four climate zones (arid, semi-arid, semi-humid, and humid) during the different subperiods between 2001 and 2018. The different colors indicate the period of vegetation expansion. For example, red labels the land cover change from non-vegetated land to vegetated land during the period 2001-2005. The insert pie chart shows the portion of each subperiod.
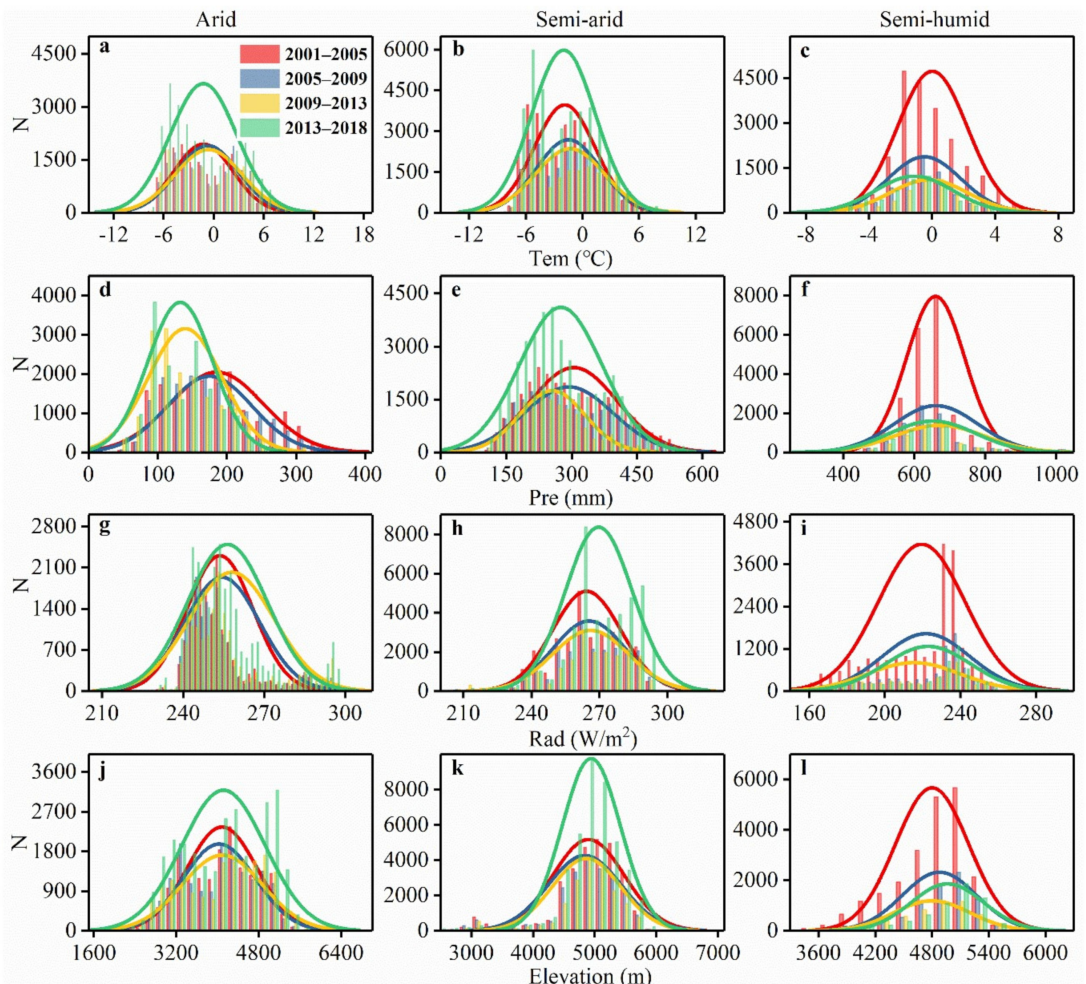

Figure 5. Frequency distribution of vegetation expansion along climate and elevation gradients for the different subperiod from 2001 to 2018. The subfigures indicate distribution of vegetation expansion during different subperiods along Tem $(\mathbf{a}-\mathbf{c})$, Pre $(\mathbf{d}-\mathbf{f})$, $\operatorname{Rad}(\mathbf{g}-\mathbf{i})$ and elevation $(\mathbf{j}-\mathbf{l})$ gradients in different climate zones. 
Comparing the positions of the distribution curves for the different subperiods, we could also find that vegetation expanded to the drier and colder places in the arid and semi-arid regions (Figure $5 \mathrm{~d}, \mathrm{e}$ ) but to the colder and higher end for the semi-humid zone (Figure $5 c, 1)$. However, the irregular distribution of the histogram, such as the bimodal distribution in Figure $5 a, j$, prevented a clear display of the direction of vegetation expansion for us. The obvious directions of vegetation expansion will be detailed along with climatic and geographical gradients in the next sub-section.

\subsection{Vegetation Expansion in Climate and Geography}

Climatically, vegetation on the TP expanded to the colder (Figure 6a; negatively, $p<0.05$ ), drier (Figure 6c; negatively, $p<0.01$ ) and higher radiation (Figure 6e; positively, $p<0.01$ ) ends over time. Spatially, the vegetation expanded northwestward along with longitudes (Figure 6b; negatively, $p<0.01$ ) and latitudes (Figure 6d; positively, $p<0.05$ ). No significant trend was found for the vegetation expanding over time along with elevation overall the TP (Figure $6 \mathrm{f} ; p>0.05$ ).
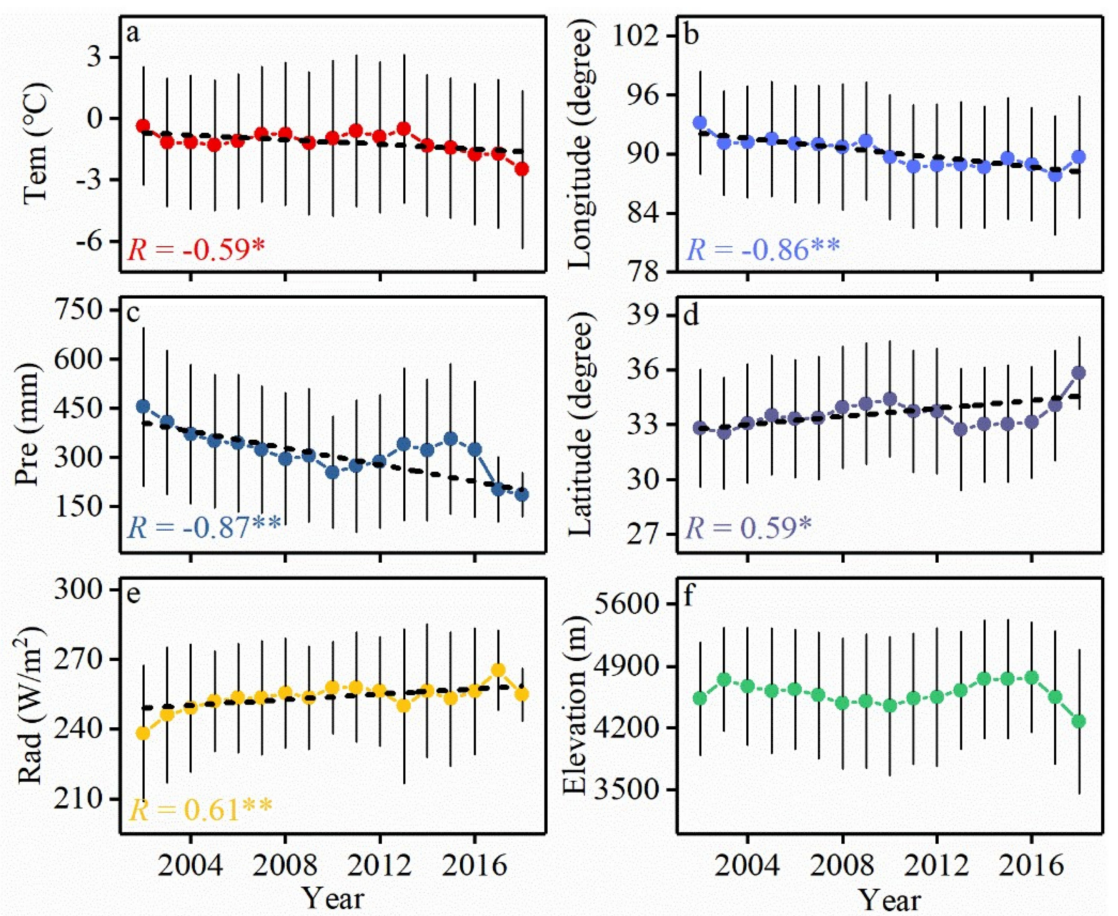

Figure 6. Trend of vegetation expansion in climate (a, Tem; c, Pre; e, Rad) and geography (b, longitude; d, latitude; f, elevation) on the TP during the period 2001-2018. Each colored point indicates the mean value of the multi-year averaged climatic variables/geographic parameters of all the pixels detected to be vegetation expansion areas in the corresponding year. The vertical black line shows the standard deviation. The dashed line indicates the linear trend of the mean value over time and $\mathrm{R}$ is the correlation coefficient with significance labelled with * and ** for the 0.05 and 0.01 levels, respectively.

In the arid and semi-arid zones, vegetation expanded to the lands with less precipitation (Figure 7d,e; negatively, $p<0.01$ ) and higher radiation (Figure 7g,h; positively, $p<0.01$ ). Spatially, the vegetation expanded westwards (Figure 8a,b; negatively, $p<0.01$ ) and upwards along with elevation (Figure 8g,h; positively, $p<0.01$ ). However, in the semi-humid zone, the vegetation expanded eastward (Figure $8 \mathrm{c}$; positively, $p<0.05$ ) to lands with lower temperature (Figure 7c; negatively, $p<0.05)$. No other statistically significant trend was found in vegetation expansion over time. 

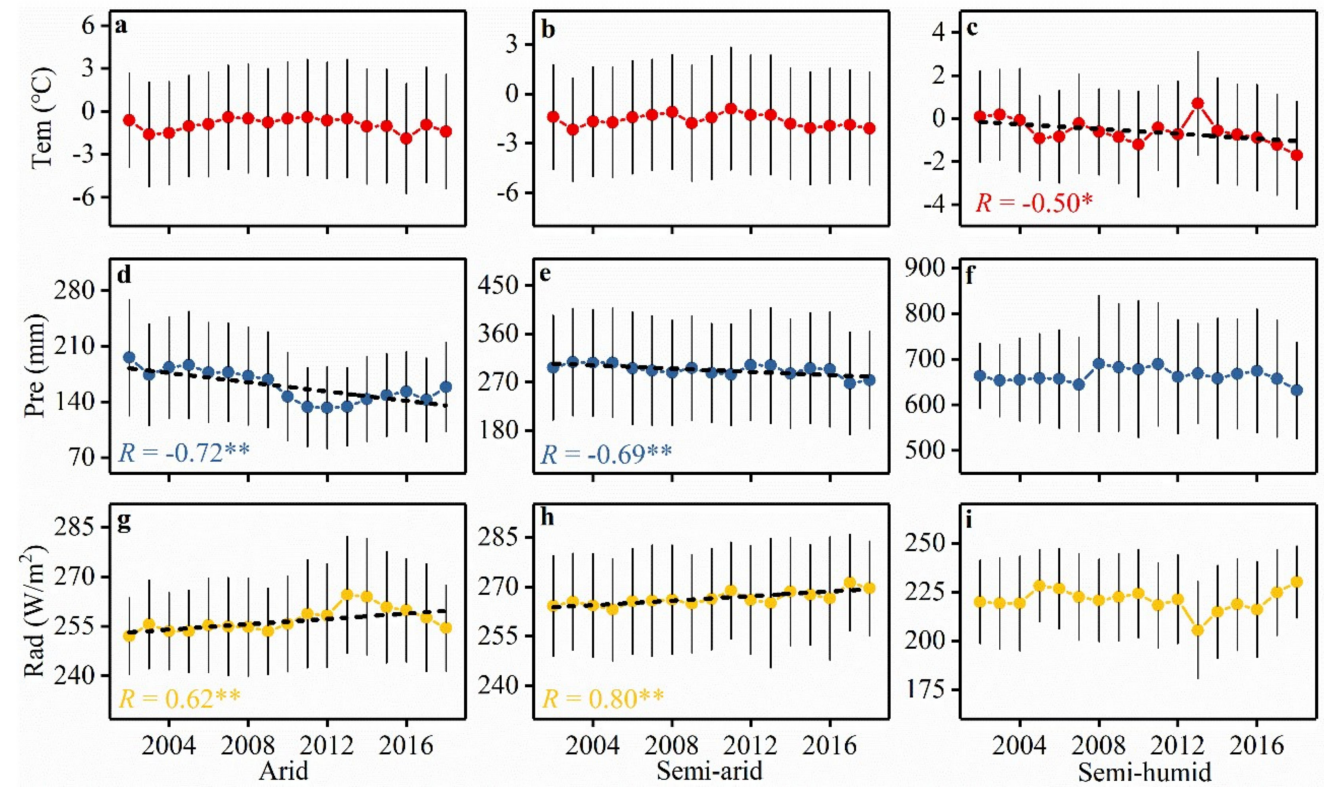

Figure 7. Trend of vegetation expansion in the climate (a-c, Tem; $\mathbf{d}-\mathbf{f}$, Pre; $\mathbf{g}-\mathbf{i}, \mathrm{Rad})$ in different climate zones during the period 2001-2018. Each colored point indicates the mean value of the multi-year averaged climatic variables of all the pixels detected to be vegetation expansion areas in the corresponding year. The vertical black line shows the standard deviation. The dashed line indicates the linear trend of the mean value over time and $\mathrm{R}$ is the correlation coefficient with significance labelled with * and ** for the 0.05 and 0.01 levels, respectively.
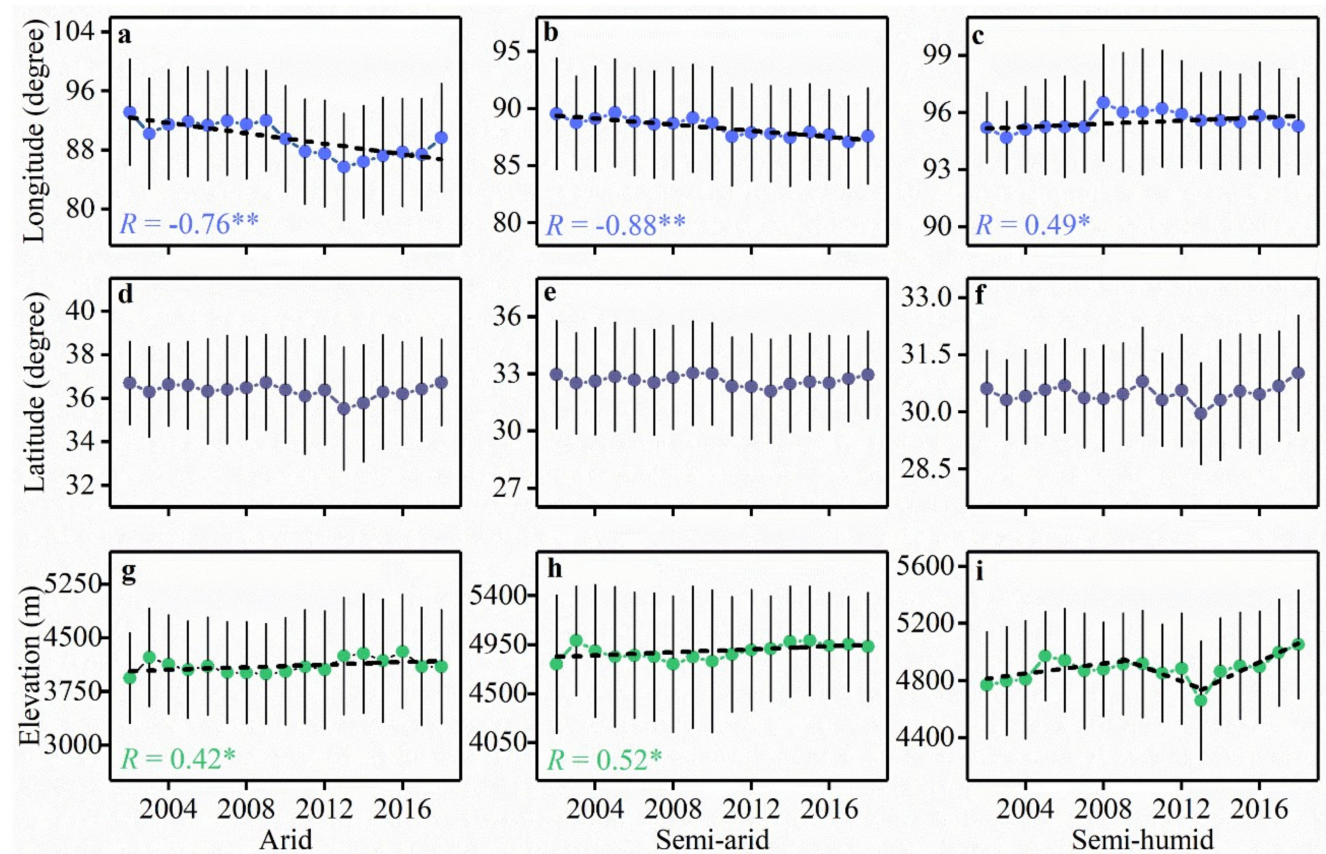

Figure 8. Trend of vegetation expansion in geography (a-c, longitude; $\mathbf{d}-\mathbf{f}$, latitude; $\mathbf{g}-\mathbf{i}$, elevation) in different climate zones during the period 2001-2018. Each colored point indicates the mean value of the geographic parameters of all the pixels detected to be vegetation expansion areas in the corresponding year. The vertical black line shows the standard deviation. The dashed line indicates the linear trend of the mean value over time and $\mathrm{R}$ is the correlation coefficient with significance labelled with * and ${ }^{* *}$ for the 0.05 and 0.01 levels, respectively. 


\subsection{Temporal Relationship between Vegetation Expansion Rate and Climate}

We examined the response of the vegetation expansion rate to climate variables (GST, GSP and GSR) with linear and non-linear (quadratic, natural log, and exponential) models (Figure 9 and Table A2). The results showed that the variability of vegetation expansion rate was positively correlated with GSP for both arid (Figure 9b and Table A2) and semi-arid (Figure 9e and Table A2) TP. However, the rate of vegetation expanded in the semi-humid zone showed a significant positive correlation with GST (Figure 9g and Table A2).
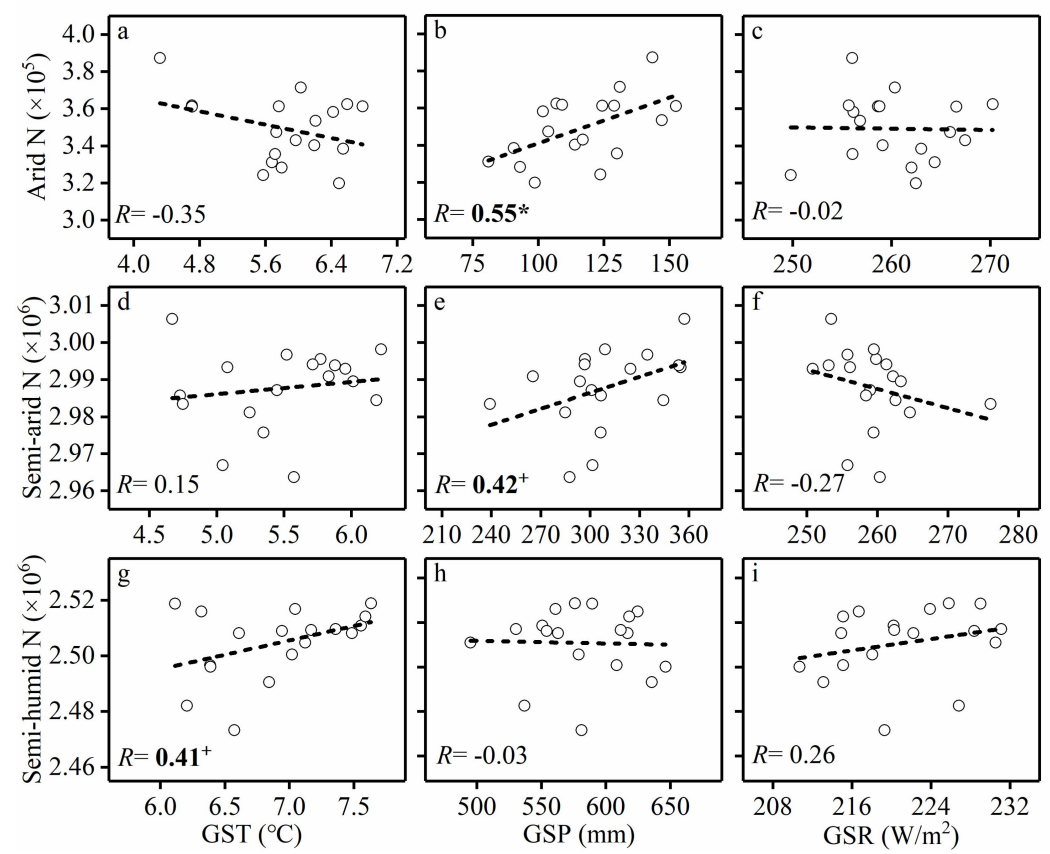

Figure 9. Linear regressions between the vegetation expansion rate and the climate variables in the different climate zones during the period 2001-2018. a-c, linear regressions between vegetation expansion rate in the arid zone and growing season air temperature (GST), growing season precipitation (GSP) and growing season radiation (GSR), respectively; $\mathbf{d}-\mathbf{f}$, as $\mathbf{a}-\mathbf{c}$ but in the semi-arid zone; $\mathbf{g}-\mathbf{i}$, as $\mathbf{a}-\mathbf{c}$ but in the semi-humid zone. The dashed line indicates the linear fitting and $R$ is the Pearson correlation coefficients with significance labelled with + and * denoting the significance at the levels of 0.1 and 0.05 , respectively.

\section{Discussion}

\subsection{Accuracy of the MODIS Land Cover Data}

The accuracy of land cover classification largely depends on the algorithm and input observation records. The MOD12Q1 collection 6 (C6) land cover data we used in this study are the latest version and the amount of spurious land cover labels has been substantially reduced compared to the previous version (Collection 5) [53]. However, uncertainty and misclassification still exist. Sulla-Menashe et al. [53] recently evaluated the accuracy of the data at the global scale. To evaluate the quality of the land cover product, they subdivided the full set of training data into 10 unique and mutually exclusive training $(90 \%)$ and testing $(10 \%)$ subsets. The results from the cross-validation showed that the data have an overall accuracy of $73.6 \%$ for the primary land cover classification layer and it was stable across time. For the IGBP classification layer we selected in this study, it has an overall accuracy of nearly 70\% during the period 2001-2016 and the types of the deciduous needleleaf forests, shrublands, wetlands, and croplands have the lowest accuracies compared with other types [53]. Specifically, the misclassification often occurs between shrublands and open forests [53]. We think the classification accuracy near or exceeding $60 \%$ is credible for our research on land cover change, 
and the accuracy less than $60 \%$, such as the closed shrublands (nearly $20 \%$ but rarely small portion on the TP), is not acceptable. The accuracy of all other types used in this study under the IGBP classification is over $60 \%$ [53]. On the TP, we found that it was different from the Vegetation Atlas of China (VAC) classification commonly used in studies of this plateau. Firstly, it is hard to separate the sub-grassland types of alpine meadows and steppes simply based on remote sensing monitoring. Therefore, in this study, alpine meadows and steppes and temperate and desert steppes are together defined as grasslands. Secondly, according to the criteria for shrublands under the IGBP scheme, shrubland is defined as the area dominated by woody perennials with 1-2 m height and over $10 \%$ coverage (closed shrublands $>60 \%$; open shrublands $10-60 \%$ ). While plants on the TP are very low-growing and cushion-shaped [68] due to the high elevation and low temperature. And this might make the area of shrublands smaller compared with the shrublands in VAC [42]. Thirdly, the savannas, termed as open forests in this study, account for $3.2 \%$ of the total area of the plateau, but this type of vegetation does not exist under the VAC classification. The open forests on the TP might be a mixture of spare forests and shrublands [53]. This, to a certain extent, makes the results of this research and previous results incomparable due to the differences in the classification method. For example, we found that evergreen broadleaf forests and deciduous broadleaf forests significantly decreased but open forests increased (Figure 3b,c,f). While in studies of Ni [44] and Zhao et al. [45], they found forests, including broadleaf forests, coniferous-broad-leaved mixed forests, and coniferous forests, would experience a large expansion. The main reason for that might be the difference in the classification schemes.

Nevertheless, compared to the fixed VAC established in the 2000s, remote sensing-based land cover classification remains to be a feasible method for large-scale continuous (annual interval) land cover observations with high spatial resolution under a same standard. However, remote sensing-based land cover classification on the TP, especially in recognizing sub-grasslands and shrublands, is expected to consider more details and refine the classification schemes. On the other hand, model-based predictions with the current satellite-based remote sensing classification are expected in the future so that the predictions can be evaluated with the continuous satellite-based vegetation monitoring.

\subsection{Land Cover Change on the TP}

The misclassification between some vegetation types, such as less accuracy in open forests and shrublands [53], makes the analysis on expansion and shrinkage of a certain land cover type inaccurate. However, the continuous expansion or shrinkage of land coverage is unlikely to be caused by noises. For instance, the coverage of evergreen broadleaf forests, deciduous broadleaf forests, and croplands continuously decreased, but the coverage of shrublands, open forests, grasslands, and water bodies increased (Figure 3). In addition, the coverage of wetlands decreased during the subperiod 2001-2010 but increased later (Figure $3 \mathrm{~h}$ ). Statistics on the change types and pixels, the conversion from evergreen and deciduous broadleaf forests to other types of forests, such as needleleaf forests, mixed forests and open forests, contributed to the continuous reduction in evergreen and deciduous broadleaf forests coverage (Table A1). Meanwhile the transition from other types of forests to open forests resulted in the continuous expansion of open forests (Table A1 and Figure 3f). The decline of evergreen and deciduous broadleaf forests is contrary to the previous prediction [45], and the reasons for it may be the results of climate change and/or human activities (e.g., urbanization and road construction). The sharp decline in the croplands is attributed to the shifting from croplands to grasslands (Table A1), which may be related to the grassland protection projects and urbanization in the past two decades (Figure 3j) [69]. The encroachment of shrubs into grasslands and barrens caused the expansion of shrublands (Table A1), and it is consistent with previous predictions [44-46]. The presence of grass on barren lands caused the dramatic expansion of the grasslands (Table A1 and Figure 3g). The wetlands, mainly distributed in the semi-humid zone, decreased during the period 2001-2010 but increased during the period 2010-2018 (Figure 3h). We examined the temperature and precipitation in the semi-humid zone and found that the growing season temperature (precipitation) increased (decreased) during the period 2001-2010 
but decreased (increased) during the period 2010-2018 (Figure A2). We believe both the change in precipitation and temperature resulted the shrinkage and expansion of wetlands. The coverage of snow and ice generally showed a flat line and significantly increased after 2015 (Figure 3k). Liu et al. [70] integrated multiple-source temperature datasets and found a slowdown of the warming trend after 1998. Sun et al. [35] recently found that the northwest TP, where snow and ice coverage was mainly distributed in, experienced an overall wetting trend since the mid-1990s. We think both the slowdown of warming rate and wetting trend contributed to the change of ice and snow coverage. Meanwhile, we also found that water bodies expanded, which was consistent with previous studies, and it was mainly attributed to the increase in precipitation over the northwest TP [35,71,72]. We think the misclassification caused the large anomalies in the coverage of needleleaf forests and mixed forests in some years (Figure $3 a, d)$.

\subsection{Vegetation Expansion under Climate Change}

We detailed the definition of vegetation expansion in this study and examined the spatial distribution, directions, and the temporal relationship with climate across the TP and in different climate zones (Figures 5-9). Our results are more comparable to previous studies. Over all the TP, we confirmed the northwestward expansion of vegetation on the TP (Figure 6), which was previously predicted in studies of $\mathrm{Ni}$ [44] and Zhao et al. [45] and recently forecasted by Gao et al. [46]. However, in different climate zones, the process of vegetation expansion is spatially heterogeneous. Spatially, vegetation in the arid and semi-arid TP mainly expanded in the boundary zone, where it is a transition zone between barrens and grasslands (Figures 1 and 4). The vegetation expanded westward to higher lands with drier and more radiating climate (Figures 7 and 8). However, in the semi-humid $\mathrm{TP}$, vegetation mainly expanded in the western part (Figure 1), where barren lands were formed by the high topography of Tanggula Mountain and Nyainqentanglha Mountain. There, the vegetation expanded eastward to higher lands ("upward") with lower temperature (Figures 7 and 8 ). Nevertheless, the spatial advance of vegetation along the elevation was not as expected to show a significant $(p>0.05)$ trend (Figure 8i). We think the drastic cooling during the period 2009-2013 (Figure A2) is responsible for that. During this period, the low temperature slowed the rate of vegetation expansion and made vegetation expand in low-elevation areas, resulting in the trend's insignificant spatial change.

The dominant climate factors are heterogeneous in contributing to the vegetation dynamics across the TP. For example, the green-up dates of vegetation in the arid areas is more sensitive to preseason precipitation than humid areas, while it is more sensitive to preseason temperature in the humid than in arid lands on the plateau [73]. Li et al. [66] also found that the "greenness" (NDVI) in the northern TP is sensitive to precipitation and radiation, while in the southern $\mathrm{TP}$, it is sensitive to temperature. In this study, we also confirmed that the vegetation expansion rate in different climatic zones has spatial heterogeneity in response to climate change. The vegetation expansion rate in arid and semi-arid zones is mainly limited by precipitation (Figure 9). There, high radiation-induced drought limits the vegetation "greenness" $[38,66,74,75]$. A recent study proved the significant increase in precipitation over the northwest TP [35], and the wetting trend might accelerate the expansion of vegetation on the arid and semi-arid lands. While the rate of vegetation expansion in semi-humid TP is mainly limited by low temperature (Figure 9) and the warming trend in recent decades contributed to the "greening" for the temperature-limited highlands.

Global climate models (GCMs) predicted a warmer and wetter TP in the future. Under the medium mitigation emission scenario (RCP4.5), Hu et al. [76] analyzed the temperature and precipitation changes in the early (2016-2035), middle (2046-2065), and end (2081-2100) periods. The results show that the mean annual temperature increase will be $0.8-1.3^{\circ} \mathrm{C}, 1.6-2.5^{\circ} \mathrm{C}$ and $2.1-3.1^{\circ} \mathrm{C}$ compared with the period of 1986-2005, respectively. Meanwhile, the annual precipitation across the TP will increase by $4.4,7.9$ and $11.7 \%$, respectively. Spatially, the temperature will increase significantly throughout the $\mathrm{TP}$, and precipitation over the northwest TP will significantly increase according to the projections. Su et al. [43] analyzed the climate change under RCP2.6 and RCP8.5 scenarios, and they also found the 
warming and wetting trend over TP both in the short term and long term. The throughout warming and humidification in the northwest TP may be the most important ecological factor driving the continuous expansion of vegetation on the TP in the future.

\section{Conclusions}

In this study, we described the land cover on the TP under the IGBP classification scheme and its variations during the period 2001-2018. Vegetation expansion was documented in trend analyses along with climatic and geographical gradients. We also examined the temporal relationships between vegetation expansion rate and climatic variables. In the past 18 years from 2001 to 2018, vegetation expanded by $33,566 \mathrm{~km}^{2}$ (1.3\% of the TP area) and the noticeable change on the TP was the expansion of vegetated lands and the shrinkage of barrens. Spatially, we confirmed that the vegetation is expanding northwestward to lands with colder, drier, and stronger radiation in climate with a higher elevation. The vegetation expansion rate across the TP is positively correlated with precipitation in the arid and semi-arid areas but limited by low temperature in the semi-humid places. Our results verified the previous model-based predictions. However, vegetation classification based on remote-sensing monitoring needs to be refined on the TP, and model predictions are expected to include the current remote sensing-based land cover categories to make it comparable with observations in the future.

Author Contributions: Conceptualization, Y.H. and X.Z.; data curation, Z.W.; formal analysis, Z.W. and M.L.; funding acquisition, X.Z.; investigation, Z.W.; methodology, Z.W. and J.Z.; project administration, X.Z.; resources, Z.W.; software, Z.W., M.L. and J.Z.; supervision, Y.H. and X.Z.; validation, J.W. and B.N.; visualization, Z.W. and J.W.; writing—original draft, Z.W.; writing—review and editing, J.W. and B.N. All authors have read and agreed to the published version of the manuscript.

Funding: This research was jointly funded by the Second Tibetan Plateau Scientific Expedition and Research (STEP) program (2019QZKK1002), the Strategic Priority Research Program of the Chinese Academy of Sciences (XDA1907030302, XDA19050502, XDA20010201), the National Key Research Projects of China (2017YFA0604801), and the National Natural Science Foundation of China (31770477).

Acknowledgments: The authors would like to acknowledge the National Aeronautics and Space Administration (NASA) for providing MODIS MCD12Q1 products and STRM products, the Institute of Tibetan Plateau Research, Chinese Academy of Sciences, for offering the land surface radiation data.

Conflicts of Interest: The authors declare no conflict of interest.

\section{Appendix A}

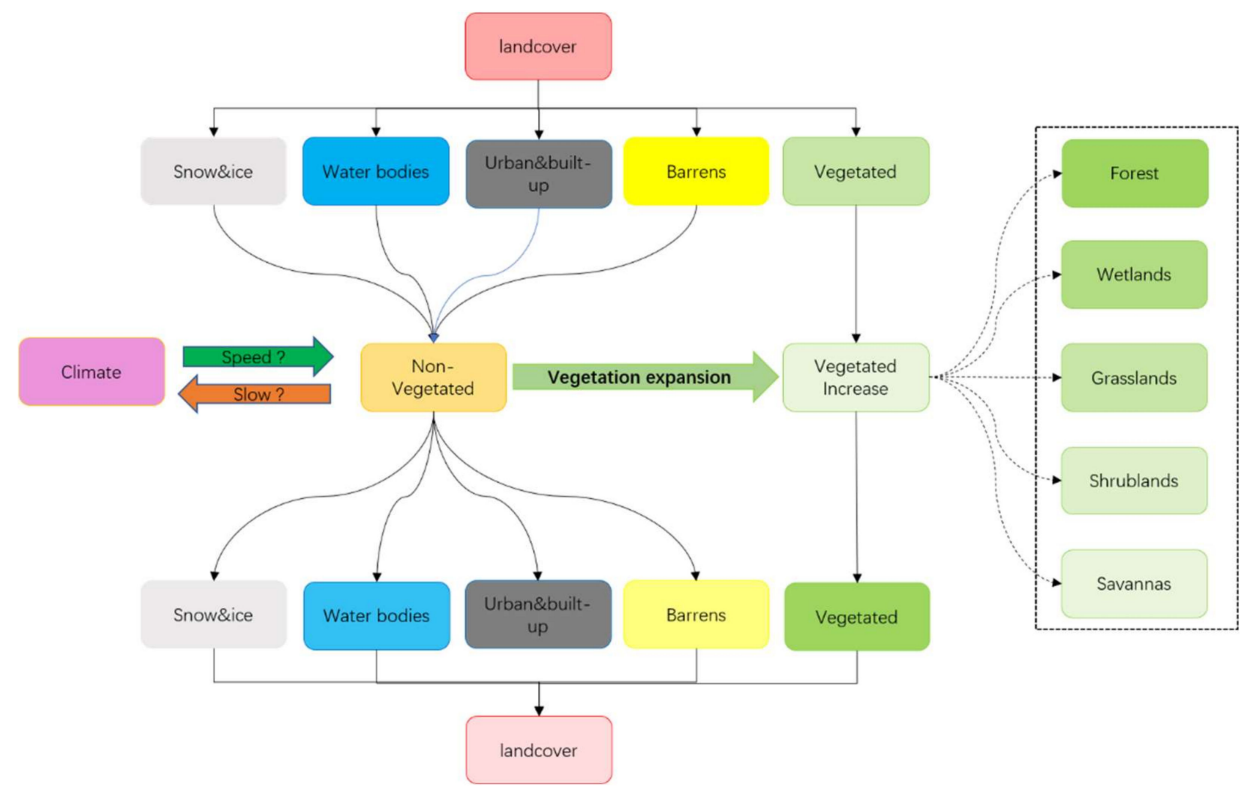

Figure A1. Flow chart of the method and design of this study. 
Table A1. Statistics on the changes in land cover conversion types and the number of pixels $(\mathrm{N})$ between 2018 and 2001.

\begin{tabular}{|c|c|c|c|c|c|c|c|c|c|c|c|}
\hline & $-\mathrm{NF}$ & -DF & -MF & -SL & -OF & -GL & $-W E$ & $-C L$ & -SI & $-B A$ & WB \\
\hline NF- & & & 12,976 & & 13,961 & 2812 & & & & & \\
\hline EF- & & & 2862 & & 1179 & & & & & & \\
\hline DF- & 2123 & & 4860 & & 6418 & 1484 & & & & & \\
\hline MF- & 19,559 & & & & 17,267 & 2644 & & & & & \\
\hline SL- & & & & & & 6219 & & & & 2486 & \\
\hline OF- & 16,017 & 2371 & 15,438 & & & 27,719 & & & & & \\
\hline GL- & 2026 & 1374 & 1923 & 12,208 & 73,600 & & 1330 & 3489 & 3614 & 100,699 & \\
\hline WL- & & & & & & 1759 & & & & & \\
\hline CL- & & & & & & 10,527 & & & & & \\
\hline SI- & & & & & & 3461 & & & & 17,865 & \\
\hline BA- & & & & 5196 & & 232,607 & & & 33,173 & & 13,588 \\
\hline WB- & & & & & & & & & & 3627 & \\
\hline
\end{tabular}

NF: Needle Forests; EF: Evergreen broadleaf Forests; DF: Deciduous Broadleaf Forests; MF: Mixed Forests; SL: Shrublands; OF: Open Forests; GL: Grasslands; WL: Wetlands; CL: Croplands; SI: Snow \& Ice; BA: Barrens; WB: Water Bodies. The NF- indicates land cover change from NF to another, and -NF shows the land cover type from one type to NF. The change type with $\mathrm{N}$ less than 1000 were omitted.

Table A2. Model intercomparison results from the models relating climatic variables (growing season temperature (GST), precipitation (GSP) and surface radiation (GSR)) with the vegetation expansion rate (VER). $p$ values less than 0.1 are in bold. nc represents that the non-linear model is not in convergence.

\begin{tabular}{|c|c|c|c|c|c|c|c|c|}
\hline $\begin{array}{l}\text { Climate } \\
\text { Variable }\end{array}$ & Climate Zone & $\begin{array}{l}\text { Model } \\
\text { Type }\end{array}$ & $\begin{array}{c}\text { Equation (x-Climate; } \\
y \text {-VER) }\end{array}$ & SE & F Value & $\mathbf{R}^{2}$ & $p$ Value & AIC \\
\hline \multirow{12}{*}{ GST } & \multirow{4}{*}{ Arid } & Linear & $y=a \times x+b$ & 0.17 & 2.15 & 0.06 & 0.16 & -8.04 \\
\hline & & Quadratic & $y=a \times x^{2}+b x+c$ & 0.15 & 4.80 & 0.39 & 0.03 & -12.67 \\
\hline & & Natural log & $y=a \times \ln (x)+b$ & 0.17 & 2.69 & 0.14 & 0.12 & -8.56 \\
\hline & & Exponential & $y=a \times \exp (b \times x)+c$ & 0.15 & 4.06 & 0.35 & 0.04 & -11.55 \\
\hline & \multirow{4}{*}{ Semi-arid } & Linear & $y=a \times x+b$ & 0.01 & 0.37 & 0.02 & 0.55 & -107.34 \\
\hline & & Quadratic & $y=a \times x^{2}+b x+c$ & 0.01 & 1.33 & 0.15 & 0.29 & -107.87 \\
\hline & & Natural log & $y=a \times \ln (x)+b$ & 0.01 & 0.30 & 0.02 & 0.59 & -107.26 \\
\hline & & Exponential & $y=a \times \exp (b \times x)+c$ & nc & nc & nc & nc & nc \\
\hline & \multirow{4}{*}{ Semi-humid } & Linear & $y=a \times x+b$ & 0.01 & 3.24 & 0.17 & 0.09 & -104.45 \\
\hline & & Quadratic & $y=a \times x^{2}+b x+c$ & 0.01 & 2.45 & 0.25 & 0.12 & -104.21 \\
\hline & & Natural log & $y=a \times \ln (x)+b$ & 0.01 & 3.08 & 0.16 & 0.10 & -104.29 \\
\hline & & Exponential & $y=a \times \exp (b \times x)+c$ & $\mathrm{nc}$ & nc & $\mathrm{nc}$ & nc & nc \\
\hline \multirow{12}{*}{ GSP } & \multirow{4}{*}{ Arid } & Linear & $y=a \times x+b$ & 0.15 & 7.10 & 0.01 & 0.02 & -12.37 \\
\hline & & Quadratic & $y=a \times x^{2}+b x+c$ & 0.16 & 3.35 & 0.31 & 0.06 & -10.41 \\
\hline & & Natural log & $\mathrm{y}=\mathrm{a} \times \ln (\mathrm{x})+\mathrm{b}$ & 0.15 & 7.15 & 0.31 & 0.02 & -12.42 \\
\hline & & Exponential & $y=a \times \exp (b \times x)+c$ & 0.16 & 3.35 & 0.31 & 0.06 & -10.41 \\
\hline & \multirow{4}{*}{ Semi-arid } & Linear & $y=a \times x+b$ & 0.01 & 3.47 & 0.18 & 0.08 & -110.46 \\
\hline & & Quadratic & $y=a \times x^{2}+b x+c$ & 0.01 & 2.28 & 0.23 & 0.13 & -109.7 \\
\hline & & Natural log & $\mathrm{y}=\mathrm{a} \times \ln (\mathrm{x})+\mathrm{b}$ & 0.01 & 3.14 & 0.16 & 0.09 & -110.15 \\
\hline & & Exponential & $y=a \times \exp (b \times x)+c$ & 0.01 & 2.23 & 0.23 & 0.14 & -109.61 \\
\hline & \multirow{4}{*}{ Semi-humid } & Linear & $y=a \times x+b$ & 0.01 & 0.01 & 0.00 & 0.91 & -101.14 \\
\hline & & Quadratic & $y=a \times x^{2}+b x+c$ & 0.01 & 0.17 & 0.02 & 0.84 & -99.54 \\
\hline & & Natural log & $y=a \times \ln (x)+b$ & 0.01 & 0.01 & 0.00 & 0.92 & -101.14 \\
\hline & & Exponential & $y=a \times \exp (b \times x)+c$ & $\mathrm{nc}$ & nc & $\mathrm{nc}$ & nc & nc \\
\hline \multirow{12}{*}{ GSR } & \multirow{4}{*}{ Arid } & Linear & $y=a \times x+b$ & 0.19 & 0.01 & 0.00 & 0.93 & -5.77 \\
\hline & & Quadratic & $y=a \times x^{2}+b x+c$ & 0.19 & 0.08 & 0.00 & 0.93 & -3.94 \\
\hline & & Natural log & $y=a \times \ln (x)+b$ & 0.19 & 0.01 & 0.00 & 0.94 & -5.78 \\
\hline & & Exponential & $\mathrm{y}=\mathrm{a} \times \exp (\mathrm{b} \times \mathrm{x})+\mathrm{c}$ & nc & nc & nc & nc & nc \\
\hline & \multirow{4}{*}{ Semi-arid } & Linear & $y=a \times x+b$ & 0.01 & 1.23 & 0.07 & 0.28 & -108.26 \\
\hline & & Quadratic & $y=a \times x^{2}+b x+c$ & 0.01 & 0.86 & 0.10 & 0.44 & -106.87 \\
\hline & & Natural log & $y=a \times \ln (x)+b$ & 0.01 & 1.26 & 0.07 & 0.28 & -108.3 \\
\hline & & Exponential & $y=a \times \exp (b \times x)+c$ & nc & nc & $\mathrm{nc}$ & nc & nc \\
\hline & \multirow{4}{*}{ Semi-humid } & Linear & $y=a \times x+b$ & 0.01 & 1.13 & 0.06 & 0.30 & -102.36 \\
\hline & & Quadratic & $y=a \times x^{2}+b x+c$ & 0.01 & 0.57 & 0.07 & 0.57 & -100.46 \\
\hline & & Natural log & $y=a \times \ln (x)+b$ & 0.01 & 1.14 & 0.07 & 0.30 & -102.37 \\
\hline & & Exponential & $y=a \times \exp (b \times x)+c$ & nc & $\mathrm{nc}$ & nc & nc & nc \\
\hline
\end{tabular}




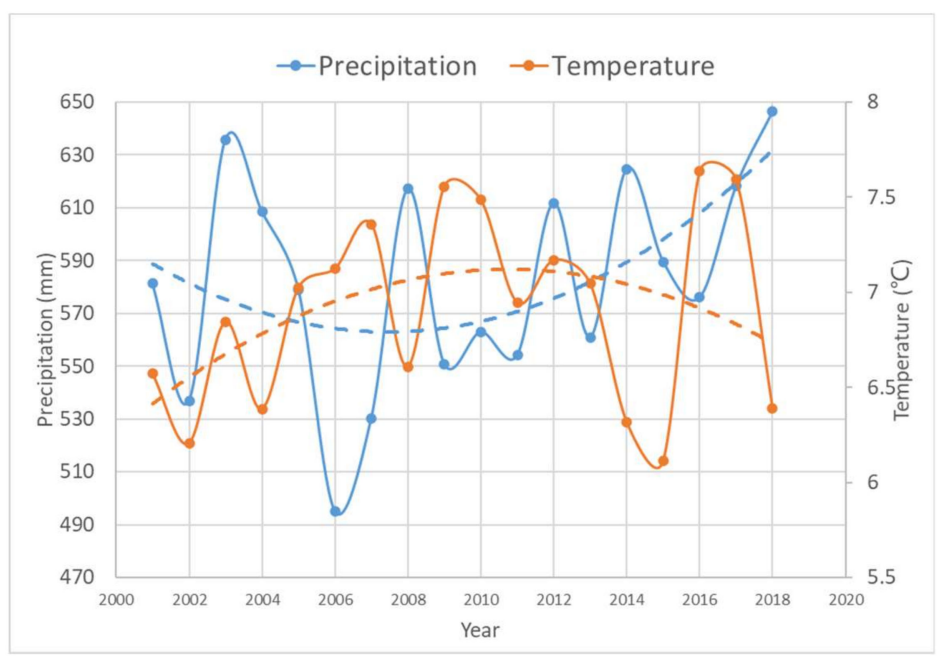

Figure A2. Interannual variations of the growing season temperature and precipitation over the semi-humid zone on the TP during the period 2001-2018.

\section{References}

1. Pepin, N.C.; Lundquist, J.D. Temperature trends at high elevations: Patterns across the globe. Geophys. Res. Lett. 2008, 35. [CrossRef]

2. Post, E.; Alley, R.B.; Christensen, T.R.; Macias-Fauria, M.; Forbes, B.C.; Gooseff, M.N.; Iler, A.; Kerby, J.T.; Laidre, K.L.; Mann, M.E.; et al. The polar regions in a 2 degrees C warmer world. Sci. Adv. 2019, 5. [CrossRef] [PubMed]

3. Serreze, M.C.; Barry, R.G. Processes and impacts of Arctic amplification: A research synthesis. Glob. Planet. Chang. 2011, 77, 85-96. [CrossRef]

4. You, Q.L.; Kang, S.C.; Pepin, N.; Flugel, W.A.; Yan, Y.P.; Behrawan, H.; Huang, J. Relationship between temperature trend magnitude, elevation and mean temperature in the Tibetan Plateau from homogenized surface stations and reanalysis data. Glob. Planet. Chang. 2010, 71, 124-133. [CrossRef]

5. Myers-Smith, I.H.; Kerby, J.T.; Phoenix, G.K.; Bjerke, J.W.; Epstein, H.E.; Assmann, J.J.; John, C.; Andreu-Hayles, L.; Angers-Blondin, S.; Beck, P.S.A.; et al. Complexity revealed in the greening of the Arctic. Nat. Clim. Chang. 2020, 10, 106-117. [CrossRef]

6. Chapin, F.S.; Sturm, M.; Serreze, M.C.; McFadden, J.P.; Key, J.R.; Lloyd, A.H.; McGuire, A.D.; Rupp, T.S.; Lynch, A.H.; Schimel, J.P.; et al. Role of land-surface changes in arctic summer warming. Science 2005, 310, 657-660. [CrossRef]

7. Harsch, M.A.; Hulme, P.E.; McGlone, M.S.; Duncan, R.P. Are treelines advancing? A global meta-analysis of treeline response to climate warming. Ecol. Lett. 2009, 12, 1040-1049. [CrossRef]

8. Brodie, J.F.; Roland, C.A.; Stehn, S.E.; Smirnova, E. Variability in the expansion of trees and shrubs in boreal Alaska. Ecology 2019, 100. [CrossRef]

9. Myers-Smith, I.H.; Forbes, B.C.; Wilmking, M.; Hallinger, M.; Lantz, T.; Blok, D.; Tape, K.D.; Macias-Fauria, M.; Sass-Klaassen, U.; Levesque, E.; et al. Shrub expansion in tundra ecosystems: Dynamics, impacts and research priorities. Environ. Res. Lett. 2011, 6. [CrossRef]

10. Blok, D.; Schaepman-Strub, G.; Bartholomeus, H.; Heijmans, M.M.P.D.; Maximov, T.C.; Berendse, F. The response of Arctic vegetation to the summer climate: Relation between shrub cover, NDVI, surface albedo and temperature. Environ. Res. Lett. 2011, 6. [CrossRef]

11. Pearson, R.G.; Phillips, S.J.; Loranty, M.M.; Beck, P.S.A.; Damoulas, T.; Knight, S.J.; Goetz, S.J. Shifts in Arctic vegetation and associated feedbacks under climate change. Nat. Clim. Chang. 2013, 3, 673-677. [CrossRef]

12. Natali, S.M.; Schuur, E.A.G.; Rubin, R.L. Increased plant productivity in Alaskan tundra as a result of experimental warming of soil and permafrost. J. Ecol. 2012, 100, 488-498. [CrossRef]

13. Sistla, S.A.; Moore, J.C.; Simpson, R.T.; Gough, L.; Shaver, G.R.; Schimel, J.P. Long-term warming restructures Arctic tundra without changing net soil carbon storage. Nature 2013, 497, 615-618. [CrossRef] [PubMed] 
14. Davidson, E.A.; Janssens, I.A. Temperature sensitivity of soil carbon decomposition and feedbacks to climate change. Nature 2006, 440, 165-173. [CrossRef] [PubMed]

15. Li, Q.; Xue, Y. Simulated impacts of land cover change on summer climate in the Tibetan Plateau. Environ. Res. Lett. 2010, 5. [CrossRef]

16. Piao, S.; Liu, Z.; Wang, T.; Peng, S.; Ciais, P.; Huang, M.; Ahlstrom, A.; Burkhart, J.F.; Chevallier, F.; Janssens, I.A.; et al. Weakening temperature control on the interannual variations of spring carbon uptake across northern lands. Nat. Clim. Chang. 2017, 7, 359-363. [CrossRef]

17. Yao, T.; Thompson, L.G.; Mosbrugger, V.; Zhang, F.; Ma, Y.; Luo, T.; Xu, B.; Yang, X.; Joswiak, D.R.; Wang, W.; et al. Third Pole Environment (TPE). Environ. Dev. 2012, 3, 52-64. [CrossRef]

18. Kang, S.C.; Xu, Y.W.; You, Q.L.; Flugel, W.A.; Pepin, N.; Yao, T.D. Review of climate and cryospheric change in the Tibetan Plateau. Environ. Res. Lett. 2010, 5. [CrossRef]

19. Kuang, X.X.; Jiao, J.J. Review on climate change on the Tibetan Plateau during the last half century. J. Geophys. Res. Atmos. 2016, 121, 3979-4007. [CrossRef]

20. Bothe, O.; Fraedrich, K.; Zhu, X. Large-scale circulations and Tibetan Plateau summer drought and wetness in a high-resolution climate model. Int. J. Climatol. 2011, 31, 832-846. [CrossRef]

21. Wu, G.X.; Liu, Y.M.; He, B.; Bao, Q.; Duan, A.M.; Jin, F.F. Thermal Controls on the Asian Summer Monsoon. Sci. Rep. 2012, 2. [CrossRef] [PubMed]

22. Molnar, P.; Boos, W.R.; Battisti, D.S. Orographic Controls on Climate and Paleoclimate of Asia: Thermal and Mechanical Roles for the Tibetan Plateau. Annu. Rev. Earth Planet. Sci. 2010, 38, 77-102. [CrossRef]

23. Ge, F.; Sielmann, F.; Zhu, X.H.; Fraedrich, K.; Zhi, X.F.; Peng, T.; Wang, L. The link between Tibetan Plateau monsoon and Indian summer precipitation: A linear diagnostic perspective. Clim. Dyn. 2017, 49, 4201-4215. [CrossRef]

24. Zhou, J.; Wen, J.; Wang, X.; Jia, D.Y.; Chen, J.L. Analysis of the Qinghai-Xizang Plateau Monsoon Evolution and Its Linkages with Soil Moisture. Remote Sens. 2016, 8, 493. [CrossRef]

25. Shen, M.; Piao, S.; Jeong, S.J.; Zhou, L.; Zeng, Z.; Ciais, P.; Chen, D.; Huang, M.; Jin, C.S.; Li, L.Z.; et al. Evaporative cooling over the Tibetan Plateau induced by vegetation growth. Proc. Natl. Acad. Sci. USA 2015, 112, 9299-9304. [CrossRef]

26. Penuelas, J.; Rutishauser, T.; Filella, I. Phenology Feedbacks on Climate Change. Science 2009, 324, 887-888. [CrossRef]

27. Yao, T.; Thompson, L.; Yang, W.; Yu, W.; Gao, Y.; Guo, X.; Yang, X.; Duan, K.; Zhao, H.; Xu, B.; et al. Different glacier status with atmospheric circulations in Tibetan Plateau and surroundings. Nat. Clim. Chang. 2012, 2, 663-667. [CrossRef]

28. Li, X.; Cheng, G.; Jin, H.; Kang, E.; Che, T.; Jin, R.; Wu, L.; Nan, Z.; Wang, J.; Shen, Y. Cryospheric change in China. Glob. Planet. Chang. 2008, 62, 210-218. [CrossRef]

29. Chen, H.; Zhu, Q.; Peng, C.; Wu, N.; Wang, Y.; Fang, X.; Gao, Y.; Zhu, D.; Yang, G.; Tian, J.; et al. The impacts of climate change and human activities on biogeochemical cycles on the Qinghai-Tibetan Plateau. Glob. Chang. Biol. 2013, 19, 2940-2955. [CrossRef]

30. Li, L.; Yang, S.; Wang, Z.Y.; Zhu, X.D.; Tang, H.Y. Evidence of Warming and Wetting Climate over the Qinghai-Tibet Plateau. Arct. Antarct. Alp. Res. 2010, 42, 449-457. [CrossRef]

31. Xie, H.; Ye, J.; Liu, X.; Chongyi, E. Warming and drying trends on the Tibetan Plateau (1971-2005). Theor. Appl. Climatol. 2010, 101, 241-253. [CrossRef]

32. You, Q.L.; Min, J.Z.; Jiao, Y.; Sillanpaa, M.; Kang, S.C. Observed trend of diurnal temperature range in the Tibetan Plateau in recent decades. Int. J. Climatol. 2016, 36, 2633-2643. [CrossRef]

33. Duan, A.; Wu, G. Change of cloud amount and the climate warming on the Tibetan Plateau. Geophys. Res. Lett. 2006, 33. [CrossRef]

34. Piao, S.; Ciais, P.; Huang, Y.; Shen, Z.; Peng, S.; Li, J.; Zhou, L.; Liu, H.; Ma, Y.; Ding, Y.; et al. The impacts of climate change on water resources and agriculture in China. Nature 2010, 467, 43-51. [CrossRef]

35. Sun, J.; Yang, K.; Guo, W.; Wang, Y.; He, J.; Lu, H. Why Has the Inner Tibetan Plateau Become Wetter since the Mid-1990s? J. Clim. 2020, 33, 8507-8522. [CrossRef]

36. Zhang, G.; Zhang, Y.; Dong, J.; Xiao, X. Green-up dates in the Tibetan Plateau have continuously advanced from 1982 to 2011. Proc. Natl. Acad. Sci. USA 2013, 110, 4309-4314. [CrossRef]

37. Yu, H.; Luedeling, E.; Xu, J. Winter and spring warming result in delayed spring phenology on the Tibetan Plateau. Proc. Natl. Acad. Sci. USA 2010, 107, 22151-22156. [CrossRef] 
38. Shen, M.; Piao, S.; Chen, X.; An, S.; Fu, Y.H.; Wang, S.; Cong, N.; Janssens, I.A. Strong impacts of daily minimum temperature on the green-up date and summer greenness of the Tibetan Plateau. Glob. Chang. Biol. 2016, 22, 3057-3066. [CrossRef]

39. Li, M.; Wu, J.; He, Y.; Wu, L.; Niu, B.; Song, M.; Zhang, X. Dimensionality of grassland stability shifts along with altitudes on the Tibetan Plateau. Agric. For. Meteorol. 2020, 291. [CrossRef]

40. Liu, H.; Mi, Z.; Lin, L.; Wang, Y.; Zhang, Z.; Zhang, F.; Wang, H.; Liu, L.; Zhu, B.; Cao, G.; et al. Shifting plant species composition in response to climate change stabilizes grassland primary production. Proc. Natl. Acad. Sci. USA 2018, 115, 4051-4056. [CrossRef]

41. Piao, S.; Cui, M.; Chen, A.; Wang, X.; Ciais, P.; Liu, J.; Tang, Y. Altitude and temperature dependence of change in the spring vegetation green-up date from 1982 to 2006 in the Qinghai-Xizang Plateau. Agric. For. Meteorol. 2011, 151, 1599-1608. [CrossRef]

42. Zhang, Y.; Qi, W.; Zhou, C.; Ding, M.; Liu, L.; Gao, J.; Bai, W.; Wang, Z.; Zheng, D. Spatial and temporal variability in the net primary production of alpine grassland on the Tibetan Plateau since 1982. J. Geogr. Sci. 2014, 24, 269-287. [CrossRef]

43. Su, F.G.; Duan, X.L.; Chen, D.L.; Hao, Z.C.; Cuo, L. Evaluation of the Global Climate Models in the CMIP5 over the Tibetan Plateau. J. Clim. 2013, 26, 3187-3208. [CrossRef]

44. Ni, J. A simulation of biomes on the Tibetan Plateau and their responses to global climate change. Mt. Res. Dev. 2000, 20, 80-89. [CrossRef]

45. Zhao, D.; Wu, S.; Yin, Y.; Yin, Z.-Y. Vegetation distribution on Tibetan Plateau under climate change scenario. Reg. Envir. Chang. 2011, 11, 905-915. [CrossRef]

46. Gao, Q.; Guo, Y.; Xu, H.; Ganjurjav, H.; Li, Y.; Wan, Y.; Qin, X.; Ma, X.; Liu, S. Climate change and its impacts on vegetation distribution and net primary productivity of the alpine ecosystem in the Qinghai-Tibetan Plateau. Sci. Total Environ. 2016, 554-555, 34-41. [CrossRef]

47. Anderson, K.; Fawcett, D.; Cugulliere, A.; Benford, S.; Jones, D.; Leng, R.L. Vegetation expansion in the subnival Hindu Kush Himalaya. Glob. Chang. Biol. 2020, 26, 1608-1625. [CrossRef]

48. Fensholt, R.; Proud, S.R. Evaluation of Earth Observation based global long term vegetation trends-Comparing GIMMS and MODIS global NDVI time series. Remote Sens. Environ. 2012, 119, 131-147. [CrossRef]

49. Yao, T.; Wu, F.; Ding, L.; Sun, J.; Zhu, L.; Piao, S.; Deng, T.; Ni, X.; Zheng, H.; Ouyang, H. Multispherical interactions and their effects on the Tibetan Plateau's earth system: A review of the recent researches. Natl. Sci. Rev. 2015, 2, 468-488. [CrossRef]

50. You, Q.L.; Fraedrich, K.; Ren, G.Y.; Pepin, N.; Kang, S.C. Variability of temperature in the Tibetan Plateau based on homogenized surface stations and reanalysis data. Int. J. Climatol. 2013, 33, 1337-1347. [CrossRef]

51. You, Q.L.; Min, J.Z.; Zhang, W.; Pepin, N.; Kang, S.C. Comparison of multiple datasets with gridded precipitation observations over the Tibetan Plateau. Clim. Dyn. 2015, 45, 791-806. [CrossRef]

52. You, Q.; Sanchez-Lorenzo, A.; Wild, M.; Folini, D.; Fraedrich, K.; Ren, G.; Kang, S. Decadal variation of surface solar radiation in the Tibetan Plateau from observations, reanalysis and model simulations. Clim. Dyn. 2013, 40, 2073-2086. [CrossRef]

53. Sulla-Menashe, D.; Gray, J.M.; Abercrombie, S.P.; Friedl, M.A. Hierarchical mapping of annual global land cover 2001 to present: The MODIS Collection 6 Land Cover product. Remote Sens. Environ. 2019, 222, 183-194. [CrossRef]

54. Friedl, M.A.; Sulla-Menashe, D.; Tan, B.; Schneider, A.; Ramankutty, N.; Sibley, A.; Huang, X. MODIS Collection 5 global land cover: Algorithm refinements and characterization of new datasets. Remote Sens. Environ. 2010, 114, 168-182. [CrossRef]

55. Abercrombie, S.P.; Friedl, M.A. Improving the Consistency of Multitemporal Land Cover Maps Using a Hidden Markov Model. IEEE Trans. Geosci. Remote Sens. 2016, 54, 703-713. [CrossRef]

56. McIver, D.K.; Friedl, M.A. Using prior probabilities in decision-tree classification of remotely sensed data. Remote Sens. Environ. 2002, 81, 253-261. [CrossRef]

57. Hutchinson, M. Anusplin Version 4.3; Centre for Resource and Environmental Studies, The Australian National University: Canberra, Australia, 2004.

58. Chen, B.; Zhang, X.; Tao, J.; Wu, J.; Wang, J.; Shi, P.; Zhang, Y.; Yu, C. The impact of climate change and anthropogenic activities on alpine grassland over the Qinghai-Tibet Plateau. Agric. For. Meteorol. 2014, 189-190, 11-18. [CrossRef] 
59. Zhao, H.; Huang, W.; Xie, T.; Wu, X.; Xie, Y.; Feng, S.; Chen, F. Optimization and evaluation of a monthly air temperature and precipitation gridded dataset with a 0.025 degrees spatial resolution in China during 1951-2011. Theor. Appl. Climatol. 2019, 138, 491-507. [CrossRef]

60. Wahba, G.; Wendelberger, J. Some new mathematical-methods for variational objective analysis using splines and cross validation. Mon. Weather Rev. 1980, 108, 1122-1143. [CrossRef]

61. Chen, Y.; Yang, K.; He, J.; Qin, J.; Shi, J.; Du, J.; He, Q. Improving land surface temperature modeling for dry land of China. J. Geophys. Res. Atmos. 2011, 116. [CrossRef]

62. Yang, K.; He, J.; Tang, W.; Qin, J.; Cheng, C.C.K. On downward shortwave and longwave radiations over high altitude regions: Observation and modeling in the Tibetan Plateau. Agric. For. Meteorol. 2010, 150, $38-46$. [CrossRef]

63. Reuter, H.I.; Nelson, A.; Jarvis, A. An evaluation of void-filling interpolation methods for SRTM data. Int. J. Geogr. Inf. Sci. 2007, 21, 983-1008. [CrossRef]

64. An, S.; Zhu, X.; Shen, M.; Wang, Y.; Cao, R.; Chen, X.; Yang, W.; Chen, J.; Tang, Y. Mismatch in elevational shifts between satellite observed vegetation greenness and temperature isolines during 2000-2016 on the Tibetan Plateau. Glob. Chang. Biol. 2018, 24, 5411-5425. [CrossRef]

65. Kadel, I.; Yamazaki, T.; Iwasaki, T.; Abdillah, M.R. Projection of future monsoon precipitation over the central Himalayas by CMIP5 models under warming scenarios. Clim. Res. 2018, 75, 1-21. [CrossRef]

66. Li, L.; Zhang, Y.; Wu, J.; Li, S.; Zhang, B.; Zu, J.; Zhang, H.; Ding, M.; Paudel, B. Increasing sensitivity of alpine grasslands to climate variability along an elevational gradient on the Qinghai-Tibet Plateau. Sci. Total Environ. 2019, 678, 21-29. [CrossRef]

67. Zhang, C.; Tang, Q.H.; Chen, D.L. Recent Changes in the Moisture Source of Precipitation over the Tibetan Plateau. J. Clim. 2017, 30, 1807-1819. [CrossRef]

68. He, Y.T.; Kueffer, C.; Shi, P.L.; Zhang, X.Z.; Du, M.Y.; Yan, W.; Sun, W. Variation of biomass and morphology of the cushion plant Androsace tapete along an elevational gradient in the Tibetan Plateau. Plant Spec. Biol. 2014, 29, E64-E71. [CrossRef]

69. Luan, W.; Li, X. Rapid urbanization and its driving mechanism in the Pan-Third Pole region. Sci. Total Environ. 2021, 750, 141270. [CrossRef]

70. Liu, Y.; Zhang, Y.; Zhu, J.; Huang, K.; Zu, J.; Chen, N.; Cong, N.; Stegehuis, A.I. Warming slowdown over the Tibetan plateau in recent decades. Theor. Appl. Climatol. 2019, 135, 1375-1385. [CrossRef]

71. Mi, H.; Fagherazzi, S.; Qiao, G.; Hong, Y.; Fichot, C.G. Climate change leads to a doubling of turbidity in a rapidly expanding Tibetan lake. Sci. Total Environ. 2019, 688, 952-959. [CrossRef]

72. Lei, Y.; Yao, T.; Bird, B.W.; Yang, K.; Zhai, J.; Sheng, Y. Coherent lake growth on the central Tibetan Plateau since the 1970s: Characterization and attribution. J. Hydrol. 2013, 483, 61-67. [CrossRef]

73. Shen, M.; Piao, S.; Cong, N.; Zhang, G.; Janssens, I.A. Precipitation impacts on vegetation spring phenology on the Tibetan Plateau. Glob. Change Biol. 2015, 21, 3647-3656. [CrossRef] [PubMed]

74. Li, M.; Wu, J.; Song, C.; He, Y.; Niu, B.; Fu, G.; Tarolli, P.; Tietjen, B.; Zhang, X. Temporal Variability of Precipitation and Biomass of Alpine Grasslands on the Northern Tibetan Plateau. Remote Sens. 2019, 11, 360. [CrossRef]

75. Huang, K.; Zhang, Y.; Zhu, J.; Liu, Y.; Zu, J.; Zhang, J. The Influences of Climate Change and Human Activities on Vegetation Dynamics in the Qinghai-Tibet Plateau. Remote Sens. 2016, 8, 876. [CrossRef]

76. Hu, Q.; Jiang, D.; Fan, G. Climate Change Projection on the Tibetan Plateau: Results of CMIP5 Models. Chin. J. Atmos. Sci. 2015, 39, 260-270.

Publisher's Note: MDPI stays neutral with regard to jurisdictional claims in published maps and institutional affiliations.

(C) 2020 by the authors. Licensee MDPI, Basel, Switzerland. This article is an open access article distributed under the terms and conditions of the Creative Commons Attribution (CC BY) license (http://creativecommons.org/licenses/by/4.0/). 